\title{
Incidence and Determinants of Complications of Percutaneous Kidney Biopsy in a Large Cohort of Native Kidney and Kidney Transplant Recipients
}

Moataz Fatthy, ${ }^{1}$ Ahmed Saleh, ${ }^{1}$ Reham A. Ahmed, ${ }^{1}$ Sameh Abouzeid, ${ }^{2}$ Seham Bakry, ${ }^{1}$ "Tarek Abdelaziz ${ }^{1}$

ABSTRACT: Objectives: This study aimed to determine the incidence and factors associated with complications for kidney biopsy. Percutaneous kidney biopsy is a useful diagnostic procedure. Haemorrhagic complications may occur following the procedure. Methods: The present study retrospectively analysed the records of patients who had percutaneous renal biopsy between March 2013 and March 2018. The cohort included both native kidney and native transplant biopsies. We have included only the first biopsy for each patient; repeat biopsies were excluded from the analysis. Results: A total of 1,198 patients (332 transplant recipients and 886 native kidney patients) were included in this study. Major complications occurred in $1.5 \%(\mathrm{n}=18)$ of patients $(1.4 \%$ in native kidney biopsies versus $1.6 \%$ in kidney transplant recipients). Adequate renal tissue (core of $>6$ glomeruli) was obtained in $91 \%$ of the patients. Data analysis revealed that the incidence of major complications in the native kidney biopsy increase with an age $>65$ years (odds ratio $=2.4 ; 95 \%$ Confidence interval $[\mathrm{CI}]=1.5-5.6$ ), estimated glomerular filtration rate $(\mathrm{eGFR})<30 \mathrm{~mL} / \mathrm{min} / \mathrm{m}^{2}$ (odds ratio $=9.7 ; 95 \% \mathrm{CI}=3.4-18.2$ ) and anaemia (odds ratio $=3.2 ; 95 \% \mathrm{CI}=1.7-5.2$ ). In transplant recipients kidney biopsy, the incidence of complications was increased with age $>65$ years (odds ratio $=2.8 ; 95 \% \mathrm{CI}=1.7-7.3$ ), eGFR $<30$ $\mathrm{mL} / \mathrm{min} / \mathrm{m}^{2}$ (odds ratio $=11.3 ; 95 \% \mathrm{CI}=3.5-16.8$ ) and anaemia (odds ratio $=2.4 ; 95 \% \mathrm{CI}=1.4-4.7$ ). Conclusion: The incidence of major complications following kidney biopsy was $1.5 \%$ for a cohort of native kidney biopsy and kidney transplant biopsies. Age $>65$ years, lower eGFR $<30 \mathrm{~mL} / \mathrm{min} / \mathrm{m}^{2}$ and anaemia were independent risk predictors for the occurrence of major complications in both native and transplant kidney biopsies.

Keywords: Biopsy; Biopsy, Needle; Complications; Safety; Kidney.

ADVANCES IN KNOWLEDGE

The incidence of major complications of percutaneous kidney biopsy is low (1.5\%) in the present cohort.

There are a number of factors that predict safety of kidney biopsy; most importantly, age, estimated glomerular filtration rate and anaemia.

\section{Application to Patient Care}

Some factors should be taken into consideration while deciding on a kidney biopsy to maximise safety.

Some factors are correctable (anaemia) and some other factors are not correctable (age and estimated glomerular filtration rate).

$\mathrm{R}$ ENAL BIOPSY IS A PROCEDURE THAT HAS been in practice for more than 100 years. ${ }^{1}$ The technique has seen substantial evolution since the introduction of percutaneous renal biopsy in the 1940s. ${ }^{2,3}$ The main aim of the technique and needle development is to increase diagnostic yield while simultaneously decreasing the rate of complications.

A percutaneous approach to obtain the kidney tissue is now considered the standard of care. The technique involves obtaining the biopsy sample using ultrasound guidance under local anaesthesia. The needles that are used during the procedure have variable gauges (14G, 16G and 18G), the outer diameter of which are $2.11,1.65$ and $1.27 \mathrm{~mm}$, respectively. Spring-loaded automatic needles have almost completely replaced the older True-Cut ${ }^{\circledR}$ needles (Merit Medical ${ }^{\circledR}$, South Jordan, Utah, USA) in most centres. A number of studies have suggested the superiority of automatic needles over Tru-Cut ${ }^{\circledR}$ needles (Merit Medical ${ }^{\circledR}$ ) in obtaining adequate renal tissue while decreasing the rate of complications. Thus, automatic spring-loaded needles have been the standard of care in most centres. ${ }^{4}$

Various major complications may occur after a percutaneous renal biopsy procedure. Those include massive bleeding requiring red blood cells (RBCs) transfusion, the requirement of angiographic embolisation to control the bleeding, nephrectomy or death. The incidence of major complications in native kidney biopsies is $2-8 \%$ as reported in the literature. ${ }^{5}$ Other less serious compilations include renal hematoma following renal biopsy and macroscopic haematuria.

A satisfactory diagnostic yield is achieved in 90-95\% of cases with the use of automatic needles and obtaining 10-20 glomeruli is usually sufficient to make a pathological diagnosis. 
Table 1: Patient characteristics at the time of percutaneous kidney Biopsy $(\mathrm{N}=1,198)$

$\begin{array}{lcccc}\text { Characteristic } & \text { Unit } & \text { Native kidney } & \text { Transplant recipient } & \text { *P Value } \\ \text { Age in years } & \text { mean } \pm \text { SD } & 48 \pm 17 & 45 \pm 14 & 0.24 \\ \text { Gender } & \text { Percentage of males } & 61 & 60 & 0.31 \\ \text { Nephrotic range proteinuria } \geq 3 \mathrm{gm} & \text { Percentage } & 35 & 31 & 0.03 \\ \text { AKI } & \text { Percentage } & 30 & 27 & 0.04 \\ \text { Haematuria } & \text { Percentage } & 61 & 57 & 0.02 \\ \text { Proteinuria } \geq 0.3 \mathrm{gm} & \text { Percentage } & 84 & 79 & 0.001\end{array}$

This study aimed to determine the incidence and factors associated with complications for kidney biopsy.

\section{Methods}

The records of the renal division of Kasr-Alainy University Hospitals were reviewed. The investigators have reviewed all the records that were available regarding patients who had undergone renal biopsy between March 2013 and March 2018. The renal division in Kasr-Alainy Centre is a large tertiary care centre; percutaneous renal biopsies are performed on regular weekly slots. All biopsies were performed using ultrasound guidance. The cohort included both, native kidney and kidney transplant recipients. The authors have included only the first biopsy for each patient; repeat biopsies were excluded from the analysis. The

Table 2: Gross haematuria by needle gauge in patients who underwent percutaneous kidney biopsy $(\mathrm{N}=1,198)$

\begin{tabular}{|c|c|c|c|c|c|}
\hline & & \multicolumn{2}{|c|}{$\begin{array}{c}\text { Gross } \\
\text { haematuria }\end{array}$} & \multirow[t]{2}{*}{ Total } & \multirow[t]{2}{*}{$\begin{array}{c}{ }^{*} P \\
\text { value }\end{array}$} \\
\hline & & No & Yes & & \\
\hline \multirow[t]{3}{*}{ Needle-gauge } & 14 & 277 & 16 & 293 & \multirow{3}{*}{0.008} \\
\hline & 16 & 445 & 9 & 454 & \\
\hline & 18 & 442 & 9 & 451 & \\
\hline Total & & 1164 & 34 & 1198 & \\
\hline
\end{tabular}

*Obtained using Kruskal-Wallis test. recorded data include epidemiological data such as age, gender, estimated glomerular filtration rate (eGFR), haemoglobin level, needle gauge and style. In the authors' centre, it is contraindicated to perform a kidney biopsy on patients with platelets $<100.000 / \mathrm{cc}$ (or International Normalised Ratio [INR] $>1.00$ ). It is also contraindicated to perform kidney biopsy when patients' haemoglobin is $<9 \mathrm{mg} / \mathrm{dL}$ as per protocol. Any uncorrected bleeding diathesis was considered a contraindication for renal biopsy.

Desmopressin is not routinely used as a premedication in kidney biopsies as per the protocol in the investigators' institution. All patients were required to stop anti-platelets one week before renal biopsy. Patients on oral anticoagulants were required to be switched to unfractionated heparin which was held at least 12 hours before attempting renal biopsy. Kidney biopsies were all performed by one investigator. To make analysis less complex, each patient had only one entry into the study.

The Statistical Package for the Social Sciences (SPSS) version 21 (IBM Corp., Chicago, Illinois, USA) was used to perform the statistical analysis. Categorical variables were compared using the Chi-squared test. Continuous variables were expressed as a mean and standard deviation. The group means were compared using the Mann-Whitney U test. Logistic regression was used to create a model to predict the development of major complications of percutaneous renal biopsy. A forward stepwise method was used in the binary

Table 3: Incidence of complications for native versus kidney transplant recipients $(\mathrm{N}=1,198)$

\begin{tabular}{|c|c|c|c|c|}
\hline \multirow[t]{2}{*}{ Complication } & \multicolumn{3}{|c|}{ n (\%) } & \multirow[t]{2}{*}{$P$ value } \\
\hline & $\begin{array}{c}\text { Total } \\
(\mathrm{N}=1,198)\end{array}$ & $\begin{array}{l}\text { Native kidney } \\
\quad(\mathrm{n}=886)\end{array}$ & $\begin{array}{l}\text { Kidney transplant recipients } \\
\qquad(\mathrm{n}=312)\end{array}$ & \\
\hline Gross haematuria & $34(2.8)$ & $25(2.8)$ & $9(3)$ & 0.1 \\
\hline Major complications & $18(1.5)$ & $13(1.5)$ & $5(1.6)$ & 0.15 \\
\hline Arterial embolization & $3(0.3)$ & $2(0.2)$ & $1(0.3)$ & 0.54 \\
\hline Need for packed RBCs transfusion & $16(1.3)$ & $12(1.4)$ & $4(1.3)$ & 0.23 \\
\hline
\end{tabular}

$R B C s=$ red blood cells 
Table 4: Predictors of occurrence of major complications in native kidney biopsy $(\mathrm{n}=886)$

\begin{tabular}{|c|c|c|c|}
\hline \multicolumn{2}{|c|}{$\begin{array}{l}\text { Unadjusted } \\
\text { analysis }\end{array}$} & \multicolumn{2}{|c|}{$\begin{array}{l}\text { Adjusted } \\
\text { analysis }\end{array}$} \\
\hline $\begin{array}{l}\text { Odds } \\
\text { Ratio } \\
\text { (CI) }\end{array}$ & $\begin{array}{c}P \\
\text { value }\end{array}$ & $\begin{array}{l}\text { Odds } \\
\text { Ratio } \\
\text { (CI) }\end{array}$ & $\begin{array}{c}P \\
\text { value }\end{array}$ \\
\hline
\end{tabular}

Age in years

\begin{tabular}{ccccc}
$18-65$ & $\begin{array}{c}1.00 \\
\text { (reference) }\end{array}$ & \multicolumn{1}{c}{$\begin{array}{c}1.00 \\
\text { (reference) }\end{array}$} & $<0.001$ \\
$>65$ & 2.7 & $<.001$ & 2.4 & \\
& $(1.7-5.7)$ & & $(1.5-5.6)$ &
\end{tabular}

Gender

$\begin{array}{lccc}\text { Male } & 1.15 & & 1.1 \\ & \begin{array}{c}(0.97- \\ 1.9)\end{array} & 0.71 & \\ \text { Female } & \begin{array}{c}1.00 \\ \text { (reference) }\end{array} & \begin{array}{c}1.00 \\ \text { (reference) }\end{array}\end{array}$

eGFR in $\mathrm{mL} / \mathrm{min} / \mathrm{m}^{2}$

$\geq 60$

1.00
(reference)

1.00

$30-59$

(reference)

$\begin{array}{ccccc}30-59 & 4.7 & & 4.5 & \\ & (1.6- & <0.001 & (2.3-13.4) & <0.001 \\ & 12.1) & & & \\ <30 & & & 9.7 & \\ & 11.1 & & (3.4-18.2) & \\ & (2.6- & & & \end{array}$

\section{Proteinuria in $\mathrm{g} / 24$ hours}

$$
<3
$$

$\geq 3$ 1.00
(reference)

$$
1.5
$$$$
\text { (0.9-3.9) }
$$

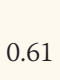

1.00

(reference)

1.3

$(0.9-2.7)$

Needle gauge

14

$$
1.5
$$

(0.87-

1.3

(0.85-2.1)

16

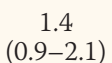

0.53

1.1

(0.7-1.9)

0.73

18

1.00
(reference)

1.000

(reference)

Haemoglobin in mg/dL

\section{$>13$}

11-13

9-11

\section{Platelets per $\mathrm{cm}^{3}$}

$>150,000$

$100,000-150,000$

$$
\begin{gathered}
1.00 \\
\text { (reference) }
\end{gathered}
$$$$
0.47
$$$$
\text { (reference) }
$$

\begin{tabular}{|c|c|c|c|c|}
\hline \multicolumn{5}{|l|}{ AKI } \\
\hline Yes & $\begin{array}{c}2.30 \\
(0.7-3.6)\end{array}$ & & $\begin{array}{c}1.9 \\
(0.8-5.5)\end{array}$ & \\
\hline No & $\begin{array}{c}1.00 \\
\text { (reference) }\end{array}$ & 0.37 & $\begin{array}{c}1.00 \\
\text { (reference) }\end{array}$ & 0.46 \\
\hline \multicolumn{5}{|c|}{ Glomerulonephritis } \\
\hline Yes & $\begin{array}{c}1.02 \\
(0.9-2.4)\end{array}$ & & $\begin{array}{c}1.03 \\
(0.9-2.6)\end{array}$ & \\
\hline No & $\begin{array}{c}1.00 \\
\text { (reference) }\end{array}$ & 0.25 & $\begin{array}{c}1.00 \\
\text { (reference) }\end{array}$ & 0.29 \\
\hline \multicolumn{5}{|c|}{ Pre-biopsy blood pressure in $\mathrm{mmHg}$} \\
\hline$<140$ & $\begin{array}{c}1.00 \\
\text { (reference) }\end{array}$ & & $\begin{array}{c}1.00 \\
\text { (reference) }\end{array}$ & \\
\hline $140-159$ & $\begin{array}{c}1.24 \\
(0.7-6.03)\end{array}$ & 0.79 & $\begin{array}{c}1.2 \\
(0.31-5.6)\end{array}$ & 0.81 \\
\hline$\geq 160$ & $\begin{array}{c}2.84 \\
(0.8-9.9)\end{array}$ & & $\begin{array}{c}2.3 \\
(0.55-8.6)\end{array}$ & \\
\hline \multicolumn{5}{|l|}{ Referral } \\
\hline Critical care area & $\begin{array}{c}1.3 \\
(0.8-1.9)\end{array}$ & & $\begin{array}{c}1.2 \\
(0.97-1.5)\end{array}$ & \\
\hline $\begin{array}{l}\text { Non-critical care } \\
\text { ward }\end{array}$ & $\begin{array}{c}1.00 \\
(0.75-1.2)\end{array}$ & 0.43 & $\begin{array}{c}1.00 \\
(0.92-1.1)\end{array}$ & 0.53 \\
\hline Outpatient & $\begin{array}{c}1.00 \\
\text { (reference) }\end{array}$ & & $\begin{array}{c}1.00 \\
\text { (reference) }\end{array}$ & \\
\hline
\end{tabular}$$
1.5
$$$$
\begin{gathered}
1.6 \\
(0.9-2.3)
\end{gathered}
$$$$
\text { (0.9-2.6) }
$$

$C I=$ confidence interval; eGFR = estimated glomerular filtration rate.

logistic regression.

This research was conducted in accordance with the Declaration of Helsinki. Written informed consent was obtained from all the patients. This study protocol was approved by the Kasr-Alainy Research Ethics Committee (approval number KA-19-134).

\section{Results}

There were a total of 1,198 patients who had undergone renal biopsy during the study period. The rate of major complications of the patients (including patients with repeated renal biopsies) was the same as the rate in the authors' cohort (including only the first renal biopsy for all patients). We can conclude that this was not a source of bias. What has been included in the analysis was only the first biopsy of every patient.

Baseline patients characteristics of both native and transplant recipient kidney biopsies were obtained [Table 1].

The biopsy was considered adequate and representative if 6-10 glomeruli were obtained successfully. The overall diagnostic yield of the needles of different gauges revealed a high adequacy rate (88-96\%) among all gauges [Figure 1]. 
Table 5: Predictors of occurrence of major complications in kidney transplant recipient biopsy $(\mathrm{n}=312)$

\begin{tabular}{|c|c|c|c|}
\hline \multicolumn{2}{|c|}{$\begin{array}{l}\text { Unadjusted } \\
\text { analysis }\end{array}$} & \multicolumn{2}{|c|}{ Adjusted analysis } \\
\hline $\begin{array}{l}\text { Odds } \\
\text { Ratio } \\
\text { (CI) }\end{array}$ & $\begin{array}{c}P \\
\text { values }\end{array}$ & $\begin{array}{c}\text { Odds } \\
\text { Ratio } \\
\text { (CI) }\end{array}$ & $\begin{array}{c}P \\
\text { value }\end{array}$ \\
\hline
\end{tabular}

Age in years

$18-65$ 1.0
(reference)

$<0.001$

1.0
(reference)

$<0.001$

$>65$

$$
\begin{gathered}
3.1 \\
(1.7-5.7)
\end{gathered}
$$

2.8

$(1.7-7.3)$

Gender

Male

$$
\begin{gathered}
0.8 \\
(0.7-2.9)
\end{gathered}
$$$$
0.55
$$$$
0.8
$$$$
(0.9-1.7)
$$

Female

$$
\begin{gathered}
1.0 \\
\text { (reference) }
\end{gathered}
$$$$
1.0
$$$$
\text { (reference) }
$$

eGFR in $\mathrm{mL} / \mathrm{min} / \mathrm{m}^{2}$

$$
\geq 60
$$$$
1.0
$$$$
\text { (reference) }
$$$$
<0.001
$$$$
1.0
$$$$
\text { (reference) }
$$

$30-59$

$$
5.3
$$$$
(2.4-14.3)
$$$$
<30
$$$$
12.9
$$$$
\text { (3.8-18.3) }
$$$$
5.1
$$$$
\text { (2.7-13.8) }
$$

11.3

(3.5-16.8)

Proteinuria in $\mathrm{g} / \mathrm{dL}$

$$
<3
$$$$
\geq 3
$$

1.0
(reference)

0.42

1.0

(reference)

1.3

(0.8-1.7)

1.4

(0.9-1.9)

Needle gauge

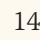

1.1
$(0.6-1.9)$

0.71

1.1

(0.8-2)

1.2
$(0.6-1.6)$

1.1

(0.7-1.9)

18

1.0

(reference)

Haemoglobin in mg/dL

$<13$

$$
\begin{gathered}
1.0 \\
\text { (reference) }
\end{gathered}
$$

$<0.001$

1.0

(reference)

$11<13$

1.8
$(0.8-5.9)$

9-11

2.8

(1.3-5.9)

Platelets

$>150,000$

$$
1.0
$$$$
\text { (reference) }
$$

0.46

1.0

(reference)

0.75

100,000-150,000

$$
\begin{gathered}
1.3 \\
(0.7-1.9)
\end{gathered}
$$

1.4

(0.8-2)

\section{AKI}

Yes

$$
1.5
$$

\begin{tabular}{|c|c|c|c|c|}
\hline Yes & $\begin{array}{c}1.7 \\
(0.6-2.2)\end{array}$ & 0.24 & $\begin{array}{c}1.4 \\
(0.6-1.8)\end{array}$ & 0.35 \\
\hline No & $\begin{array}{c}1.0 \\
\text { (reference) }\end{array}$ & & $\begin{array}{c}1.0 \\
\text { (reference) }\end{array}$ & \\
\hline \multicolumn{5}{|c|}{ Pre-biopsy blood pressure in $\mathrm{mmHg}$} \\
\hline$<140$ & $\begin{array}{c}1.0 \\
\text { (reference) }\end{array}$ & 0.07 & $\begin{array}{c}1.0 \\
\text { (reference) }\end{array}$ & 0.17 \\
\hline $140-159$ & $\begin{array}{c}2.1 \\
(0.8-5.3)\end{array}$ & & $\begin{array}{c}1.8 \\
(0.7-5.1)\end{array}$ & \\
\hline$\geq 160$ & $\begin{array}{c}3.5 \\
(0.8-4.1)\end{array}$ & & $\begin{array}{c}3.3 \\
(0.9-7.2)\end{array}$ & \\
\hline
\end{tabular}$$
\text { (0.8-2.2) }
$$

No

$$
\begin{gathered}
1.0 \\
\text { (reference) }
\end{gathered}
$$

0.42

1.3

$(0.8-4.1)$

1.0

(reference)

0.83
$C I=$ confidence interval; eGFR = estimated glomerular filtration rate .

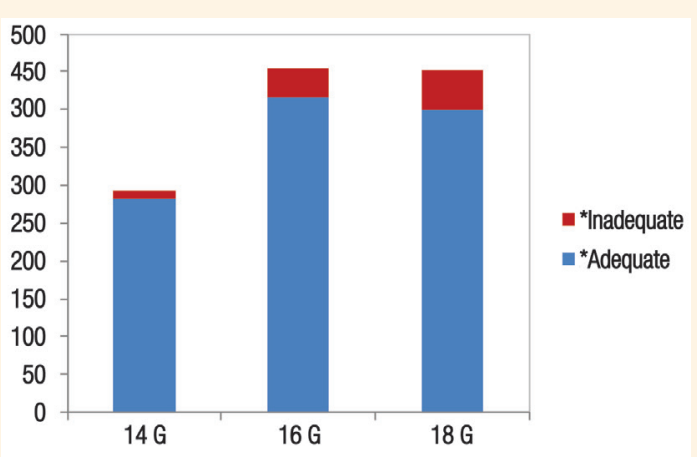

Figure 1: Adequacy of renal tissue by needle gauge. *Adequate refers to successfully obtaining 6-10 glomeruli while inadequate refers to failure to obtain 6 glomeruli.

Macroscopic haematuria occurred in $2.8 \%$ of patients $(n=34)$. The occurrence of macroscopic haematuria was significantly higher with the use of 14G needles [Table 2].

Major complications were defined as either the need for blood transfusion or the need for surgical procedure/angiographic embolisation to stop the bleeding following the biopsy procedure. The variables were adjusted for age while age was adjusted for eGFR. There were 132 patients with more than one renal biopsy; however, repeat biopsies have not been included in the analysis. A total of 18 patients (1.5\%) had major complications [Table 3]. Furthermore, predictors of occurrence of major complications following renal biopsy in native kidney biopsy and transplant, respectively, have also been tabulated [Tables 4 and 5].

\section{Discussion}

This study included 1,198 patients who underwent percutaneous renal biopsy; this included 332 transplant recipients and 886 native kidney patients. Major complications, defined as either the need for blood transfusion, surgery or arterial embolisation,

Chronic Allograft Nephropathy 
occurred in $1.5 \%$ of patients. Gross haematuria occurred in only $2.8 \%$ of patients. This emphasises the overall safety of the percutaneous renal biopsy procedure, a finding that has been demonstrated by previous reports. ${ }^{6,7}$ Adequate renal tissue was obtained in $91 \%$ of patients. There were a number of factors that predicted the development of complications. Age $>65$ years, eGFR $<30 \mathrm{~mL} / \mathrm{min} / \mathrm{m}^{2}$ and anaemia (haemoglobin $<9 \mathrm{mg} / \mathrm{dL}$ ) were associated with an increased risk of developing major complications. The incidence of major complications was not statistically significant among different needle gauges. The use of either $14 \mathrm{G}$ or $16 \mathrm{G}$ was associated with more adequate renal tissue, which was statistically significant $(P=$ $0.001)$. This study is one of the largest reports of kidney biopsy safety and complications in a cohort of both native kidneys and kidney transplant recipients.

Complications after the procedure of percutaneous renal biopsy included the observation of peri-nephric hematomas, which had an incidence of $60-70 \%$ in previous reports. Nevertheless, on most occasions, peri-nephric hematomas are not clinically meaningful and thus should not be regarded as an alarming complication. ${ }^{8}$ There are a number of other haemorrhagic complications, which include macroscopic haematuria, major bleeding requiring surgery or angiographic embolisation. A number of factors have been suggested to be associated with the potential haemorrhagic complications that can be divided into procedure-related factors and patientrelated factors. Patient related factors include age $>40$ years, female gender, elevated serum creatinine and lower haemoglobin level at the time of the procedure., ${ }^{5,9,10}$ The main procedure related factor was the use of $14 \mathrm{G}$ needles. It was observed that the increased number of passes due to the use of smaller diameter needles did not lead to increased haemorrhagic complications. ${ }^{11,12}$

Many previous studies have found that the complication rates were lower with the use of small diameter biopsy needles. ${ }^{6,13-15}$ In a nationwide registry in Norway, the incidence of major complications was found to be $0.9 \%{ }^{16}$ In the current study, the incidence of major complications was not affected by needle gauge; however, the use of $18 \mathrm{G}$ was associated with the occurrence of more frequent gross haematuria. The explanation for this observation was that the small gauge needles allowed easy deviation of the needle towards the high-density vessels in the pelvis. In another small cohort of 86 patients, the use of $14 \mathrm{G}$ needles was associated with more frequent hematoma following the percutaneous renal biopsy procedure. ${ }^{17}$
A large meta-analysis of more than 9,000 patients who underwent percutaneous native kidney biopsy found that the use of $14 \mathrm{G}$ needles was associated with a higher incidence of packed RBCs transfusion. ${ }^{5}$ The incidence of haemorrhagic complications, as reported in this meta-analysis, was macroscopic haematuria in $3.5 \%$ and the requirement for packed RBCs transfusion in $0.9 \%$ of patients. Anaemia is another important predisposing factor for the occurrence of post procedure haemorrhagic complications. This has been evident in previous reports. ${ }^{16}$

Data on kidney transplant biopsy complications stratified by needle gauge is scarce. However, one prospective randomised trial found no statistically significant difference between the three needle diameters (14G, 16G and 18G) in the incidence of major complications. The use of $14 \mathrm{G}$ needles was associated with more pain. ${ }^{18}$ However, that study was limited by the small sample size; the present study cohort provides a larger sample of transplant patients.

One of the strengths of the current study is that the cohort included both, native and renal transplant recipient patients. Different needle gauges are well represented in the sample.

Nevertheless, the study has a number of limitations. Firstly, the number of needle passes for each biopsy could not be determined. Secondly, this is a single centred study; a multi-centred study would provide more data about the difference in operators' expertise. Thirdly, the incidence of post-biopsy renal hematoma was not reported in the present study as the records did not provide sufficient data to include this complication in the analysis. Lastly, the study protocol specified recording only the first biopsy for every patient. This is closely comparable to the rate of major complications in the main cohort. We therefore do not count this as a major source of bias.

\section{Conclusion}

The incidence of major complications following kidney biopsy was $1.5 \%$ for a cohort of patients undergoing native kidney biopsy and age $>65$ years, lower eGFR $\left(<30 \mathrm{~mL} / \mathrm{min} / \mathrm{m}^{2}\right)$ and anaemia (haemoglobin $<9$ $\mathrm{mg} / \mathrm{dL}$ ) were independent risk predictors for the occurrence of major complications in both native and transplant kidney biopsies.

\section{CONFLICTS OF INTEREST}

The authors declare no conflicts of interest.

\section{FUNDING}

No funding was received for this study. 


\section{AUTHORS' CONTRIBUTION}

MF, AS and TA contributed to research idea development, data collection and data analysis. All authors contributed to the drafting of the manuscript, while SA, SB and RAA revised manuscript. All authors approved the final version of the manuscript.

\section{References}

1. Cameron JS, Hicks J. The introduction of renal biopsy into nephrology from 1901 to 1961: A paradigm of the forming of nephrology by technology. Am J Nephrol 1997; 17:347-58. https://doi.org/10.1159/000169122.

2. Iversen P, Brun C. Aspiration biopsy of the kidney. Am J Med 1951; 11:324-30. https://doi.org/10.1016/0002-9343(51)90169-6.

3. Alwall N. Aspiration biopsy of the kidney, including i.a. a report of a case of amyloidosis diagnosed through aspiration biopsy of the kidney in 1944 and investigated at an autopsy in 1950. Acta Med Scand 1952; 143:430-5.

4. Riehl J, Maigatter S, Kierdorf H, Schmitt H, Maurin N, Sieberth HG Percutaneous renal biopsy: Comparison of manual and automated puncture techniques with native and transplanted kidneys. Nephrol Dial Transplant 1994; 9:1568-74

5. Corapi KM, Chen JL, Balk EM, Gordon CE. Bleeding complications of native kidney biopsy: a systematic review and metaanalysis. Am J Kidney Dis 2012; 60:62-73. https://doi.org/10.105 3/j.ajkd.2012.02.330

6. Manno C, Strippoli GF, Arnesano L, Bonifati C, Campobasso N, Gesualdo L, et al. Predictors of bleeding complications in percutaneous ultrasound-guided renal biopsy. Kidney Int 2004; 66:1570-7. https://doi.org/10.1111/j.1523-1755.2004.00922.x.

7. Korbet SM. Percutaneous renal biopsy. Semin Nephrol 2002; 22:254-67. https://doi.org/10.1053/snep.2002.31713.

8. Doyle AJ, Gregory MC, Terreros DA. Percutaneous native renal biopsy: comparison of a 1.2-mm spring-driven system with a traditional 2-mm hand-driven system. Am J Kidney Dis 1994; 23:498-503. https://doi.org/10.1016/s0272-6386(12)80370-2.
9. Whittier WL, Korbet SM. Timing of complications in percutaneous renal biopsy. J Am Soc Nephrol 2004; 15:142-7. https:// doi.org/10.1097/01.asn.0000102472.37947.14.

10. Joseph AJ, Compton SP, Holmes LH, Annand A, Self SE, Fitzgibbon WR, et al. Utility of percutaneous renal biopsy in chronic kidney disease. Nephrology (Carlton) 2010; 15:544-8. https://doi.org/10.1111/j.1440-1797.2010.01293.x.

11. Constantin A, Brisson ML, Kwan J, Proulx F. Percutaneous USguided renal biopsy: A retrospective study comparing the 16-gauge end-cut and 14-gauge side-notch needles. J Vasc Interv Radiol 2010; 21:357-61. https://doi.org/10.1016/j.jvir.2009.11.005.

12. Burstein DM, Korbet SM, Schwartz MM. The use of the automatic core biopsy system in percutaneous renal biopsies: a comparative study. Am J Kidney Dis 1993; 22:545-52. https:// doi.org/10.1016/s0272-6386(12)80927-9.

13. Eiro M, Katoh T, Watanabe T. Risk factors for bleeding complications in percutaneous renal biopsy. Clin Exp Nephrol 2005; 9:40-5. https://doi.org/10.1007/s10157-004-0326-7.

14. Parrish AE. Complications of percutaneous renal biopsy: a review of 37 years' experience. Clin Nephrol 1992; 38:135-41.

15. Briganti EM, Dowling J, Finlay M, Hill PA, Jones CL, Kincaid-Smith PS, et al. The incidence of biopsy-proven glomerulonephritis in Australia. Nephrol Dial Transplant 2001; 16:1364-7. https:// doi.org/10.1093/ndt/16.7.1364.

16. Tøndel C, Vikse BE, Bostad L, Svarstad E. Safety and complications of percutaneous kidney biopsies in 715 children and 8573 adults in Norway 1988-2010. Clin J Am Soc Nephrol 2012; 7:1591-7. https://doi.org/10.2215/CJN.02150212.

17. Hogan JJ, Mocanu M, Berns IS. The Native Kidney Biopsy: Update and Evidence for Best Practice. Clin J Am Soc Nephrol 2016; 11:354-62. https://doi.org/10.2215/CJN.05750515.

18. Nicholson ML, Wheatley TJ, Doughman TM, WhiteSA, Morgan JDT, Veitch PS, et al. A prospective randomized trial of three different sizes of core-cutting needle for renal transplant biopsy. Kidney Int 2000; 58:390-5. https://doi.org/10.1046/j.1523-1755.2000.00177.x. 